Bovine growth hormone meets new safety concerns

\begin{abstract}
Washington. The controversy surrounding recombinant bovine growth hormone (rbGH), a genetically engineered animal drug, surfaced again last week after a government report suggested further evaluation of its risk to humans.

The report* by the US General Accounting Office (GAO) recommended that the US Food and Drug Administration (FDA) withhold its approval until more is known about its indirect impact on food from cows that have been given the drug. The GAO's findings could represent a considerable setback for the four companies - American Cyanamid Company, Elanco (a division of Eli Lilly \& Company), Monsanto Company and Upjohn Company - seeking approval from FDA to market their versions of $\mathrm{rbGH}$ in the United States. The drug can be used to boost milk production in dairy cows by 10-25 per cent.
\end{abstract}

The report concludes that even though FDA has been aware for some time that rbGH-treated cows have a higher incidence of mastitis (inflammation of the udder), the agency has failed to gather the data to determine whether this would result in an increase in the use of antibiotics and therefore higher antibiotic residues in meat and milk - so-called 'indirect' health effects. A congressional aide to US Representative Ted Weiss (Democrat, New York), one of nine congressmen to request that GAO evaluate the thoroughness of FDA's investigational review process for rbGH, called this a "serious shortcoming" in the review process.

GAO went on to recommend that until FDA has evaluated these indirect human food safety risks, the agency should suspend the sale of meat and milk products from rbGH-treated cows. FDA approved the commercial sale of meat and milk from experimental herds in late 1985 after deciding it was safe for human consumption.

Because the report was more than two years in the making, it says little that is new to the FDA, says Gerald Guest, director of the FDA's Center for Veterinary Medicine - the division of FDA that will decide whether or not to approve rbGH for use in

\title{
Dutch flower may be too safe to test new biotechnology laws
}

London. A white chrysanthemum is destined to become the first test of European legislation on the commercialization of genetically modified organisms when it is submitted to the Dutch authorities later this month. But the flower, called Floriant, may be too ordinary to serve as a good test case.

Originally pink, the chrysanthemum has been altered with DNA from another strain so that the flowers are white. Florigene, the company concerned, feels that using such a 'neutral' product to test the system will make progress easier. Although it is not expecting a great commercial return from Floriant, the company hopes that the flower will pave the way for other products being developed. While still in the realm of cut and ornamental flowers, these products will have improved resistance to diseases and pests.

Although recognizing the value of testing the system, others in the biotechnology industry do not understand why Florigene is using a product that is so simple and is not necessarily a commercial priority. Don Emlay, director of regulatory affairs for Calgene, a California biotechnology company, says that he doubts whether the knowledge gained would offset the cost in time, effort and people involved. The test comes when most of the countries of the European
Communities have at last introduced legislation to meet two directives on the subject passed by the European Council of Environment Ministers in April 1990.

"There are other ways of interacting with regulatory agencies that can lead to a better understanding without having to go through a test case," he says. Calgene has recently applied to the US Food and Drug Administration and Department of Agriculture for permission to grow and market its Flavr Savr rot-resistant tomato (see Nature 357, 352; 1992).

Unlike Europe, the United States has recently instituted regulations to cover genetically altered foods, and Emlay feels that Flavr Savr's advantage as a test case lies in the problems it raises. "Concerns for safety are greater with fresh foods than with foods that will be processed or non-foods" he said. "The tomato is a very good first product because it raises all the issues up front."

Contained trials and field trials of genetically modified organisms have been conducted in Europe and the United States for some years. However, those trials are usually carried out with such precautions as netting and barrier plants that lessen the chance of genetically altered material spreading beyond the test field.

Ian Mundell dairy cows. The problem of indirect health effects is still an "open question", says Guest. "It's one that has arisen before and that will be part of what has to be resolved before the drug can be approved", he says.

Guest says that he is not concerned about the safety of milk from the 700 or so cows now being treated with rbGH because it is so carefully regulated. "The real question is, if you were to approve it [rbGH] and it becomes widely used in a less-controlled fashion, would there then be a problem?"

Predictably, news of GAO's findings was welcomed by Jeremy Rifkin's consumer watchdog group, the Foundation on Economic Trends. The group, which has led a seven-year campaign to keep rbGH off the market citing concerns for human and animal health, filed a legal petition with FDA last week calling for full compliance with GAO's recommendations.

In a separate but related GAO report ${ }^{\dagger}$, FDA was criticized once again for its failure to develop a comprehensive strategy for monitoring animal drug residues in milk. The report highlighted the large gap between the number of drugs used to treat dairy cows, which may leave residues in milk, and the number of drugs that are routinely tested for at the state level and by FDA.

Diane Gershon

* Recombinant Bovine Growth Hormone: FDA Approval Should Be Withheld Until the Mastitis Issue is Re solved (GAO/PEMD 92-26, 6 Aug 1992)

+ Food Safety and Quality: FDA Strategy Needed to Address Animal Drug Residues in Milk (GAO/RCED 92 209, 5 Aug 1992)

\section{University scientists to be investigated for conflicts of interest}

Washington. A powerful congressman has turned his investigative team loose on Stanford University and the University of California after receiving reports from a whistleblower of potential conflicts of interest among university scientists, according to a report last week in the San Jose (California) Mercury News. Following a tip from Paul Biddle, the former government accountant who initiated the 1989 indirect cost investigation at Stanford, the staff of Representative John Dingell (Democrat, Michigan) are investigating scientists at the two universities who may have used the results of government-funded experiments to benefit private companies or have channelled federal grant dollars to private research. Dingell's oversight and investigations subcommittee of the House Energy and Commerce Committee has tentatively planned a hearing for late September. According to the news report, the subcommittee intends to widen the investigation to universities across the United States. A subcommittee staff member confirmed that an investigation is under way. Traci Watson 